\title{
CHALLENGES OF TEACHING ORAL ENGLISH IN NIGERIAN HIGH SCHOOLS
}

\author{
Joshua Usman ${ }^{1}$ \\ Lynda Jummai Mustafa² \\ English Department, IBB University, P.M.B. 11, Lapai, Niger, Nigeria \\ 1 usmanauta@yahoo.com \\ 2 mustafalinda994@gmail.com
}

\begin{abstract}
This study advocates for greater emphasis on the acquisition of oracy skills whereby this component of English is totally neglected in our higher schools. It identifies and examines some of the major challenges that the teaching of oral English could face; thereby proffering some possible solutions that could improve the teaching of oral English in our secondary schools. Questionnaires were used to seek teachers' and students' opinions concerning the problem. The research participants consisted of the teachers of English Language and students, particularly, Senior Secondary Schools Students (SSSI-SSS III) within four selected schools. The results have shown that interference of mother tongue, unqualified teachers and dearth of relevant teaching materials are the major challenges. The study suggested that (i) a high degree of motivation in both students and teachers, and (ii) the teachers' competence in the subject and their mastery of the techniques of imparting knowledge in it are the basic the solutions. Teachers and Language instructors should identify these problems, face the challenges through practical classes and improvisation and also insist on standards.
\end{abstract}

Keywords: Oral English, Spoken English, Challenges, oracy skills

\section{Introduction}

The provision of adequate instruction in oral English is regarded as a sine qua non to the acquisition of the basic skills of the language. Oral English was introduced in 1977 as part of English language paper in the teachers' grade II certification examination in Nigeria. Presently this component of English language constitutes a sub-section in English language paper in NECO, TCII and WAEC examinations and also receives prominence in English language syllabuses especially in our secondary schools. Consequently, it is obvious that learners of English language as a second language are mostly faced with the problem of oral proficiency in terms of appropriate pronunciation of English sounds (phonemes) either by virtue of being a 
new language or mother tongue or first language interference. However, there has been emphasis on the quest for Standard English, hence; an English language learner must aim at proficiency to a degree of the standard form (Standard English or Received Pronunciation). This enables the learner to acquire adequate competence for practical purpose of everyday communication. It is on this note, that much emphasis and efforts should be placed on the teaching of oral English because it will help the learner to develop his or her pronunciation sufficiently to permit effective communication with both native speakers and non-native users. Similarly, it is obvious that common mistakes identified among the learners of English as a second language today include improper pronunciation, mispronunciation, poor intonation, as well as misrepresentation of phonetic sounds. For instance, most students misplace the qualities and length of vowels. It is in view of these problems that recent development in language teaching and learning has made the teaching and learning of oral English not only a necessity but also a pre-requisite for assessing the learner's competence in language use and acquisition. Therefore, since emphasis has shifted to studying varied rules aimed at the identification, interpretation and reproduction of English sounds (phonemes), there is every cause to emphasise and to review the teaching of oral English especially in post-primary schools. Furthermore, speech is regarded as persona which represents an individual's ability to articulate phonemes according to some established norms. It also entails the ability of an individual to identify and understand the representation and meaning of English sounds. It is quite unfortunate that most of our secondary school learners do not exhibit the knowledge of oral English when using the language which could be associated with the aforementioned factors. In a nutshell, there is the need for concern. Thus, it is necessary to emphasise and encourage the study and understanding of oral English by learners. Oral proficiency should be made inherent in both teachers and learners (students). Jowitt (1991) confirms that the emphasis on proficiency in spoken English was introduced in the New National Curriculum in English language for Nigerian Secondary Schools in the 1980s. It was previously neglected in the teaching of English in Nigeria as oral English was made optional for the West African School Certificate students (though a compulsory course for teacher grade II examinations). Roach (2000) confirms that pronunciation teaching has not always been popular with teachers and language theorists and in the 1970s and 1980s. It was fashionable to treat it as a rather outdated activity. It was claimed that it makes learners try to sound like native speakers of Received Pronunciation, which became difficult and led to repetitive exercises, and it also failed to give importance to communication.

Jowitt (1991) comments about the negligence of oral English teaching on teachers. He stated that pupils unconsciously relied on mother tongue models when deprived of consistently reliable guidance from teachers, as indeed many of teachers did: assuming that there was a perfect correspondence between sound and spelling. They use orthography as their guide to pronunciation. Anthony (2001) and Uche (1998) emphasise the difficulties of acquiring oracy skills. According to Williams (1990), the factors to be enumerated could be categorised under one factor - the interference of mother tongue. It is worth noting that for the non-native speakers, the mother tongue always affects the acquisition of the second language. This has 
always, been a major problem in oral English or pronunciation teaching especially in Nigerian schools. Unoh (1986) also examines the situation of oral English in Nigerian secondary schools. He asserts that teaching of English pronunciation in Nigeria suffers from peculiar handicaps unknown to the teaching of English language or any other school subject (for that matter). For any subject to be effectively taught, there are at least two very important conditions that must be met: (i) a high degree of motivation on the part of both student and teacher; and (ii) the teachers' competence in the subject, and his or her mastery of the techniques of imparting knowledge in it. While the aforementioned conditions are rarely achieved in the teaching of English Language, they are also hardly met in the case of the teaching and learning of English pronunciation. Okoli (2000) comments on the need to be proficient in the sound system of a new language and explains that English should be pronounced in the accent normally chosen as the standard form especially the model most often recommended for foreign learners studying standard British English and also Received Pronunciation.

The teaching of oral English in Nigerian secondary schools has previously been overlooked. However, recent development in the teaching of English Language requires greater emphasis on this aspect of English language. Oral English complements the understanding and the use of English language so as to improve the standard of spoken English. According to Idris (2001), not much has been achieved since the introduction of oral English in our West African School Certificate and National Examination Council due to the problems associated with the teaching and learning of oral English. There are existing publications on phonology written by Linguists such as A.C. Gimson, Daniel Jones, David Jowitt, Peter Roach, among others. Recently, there is the emergence of new publications particularly on Oral English by other language teachers, researchers and scholars such as Mannell, Cox, and Harrington (2009), Akperero (2000), Enyeazu (2001), and Idris (2001). This development has gone a long way in bringing oral English into focus. Its recent inclusion in the English Language Examination Paper (Test of Orals) has drawn the attention of many teachers and students.

Consequently, the teaching of oral English is rather weighed down by various factors which have contributed to the slow pace and ineffectiveness in teaching the course. These factors include poor background, interference of mother tongue, unqualified teachers, poor teaching methodology, lack of constant practice, lack of orientation and facilities, and shortage and limited accessibility to relevant books. Most of the students in our secondary schools are faced with either one of the problems or the other. Some are deficient due to more than one problem especially students from rural and poor backgrounds. This study examines some of the major challenges that the teaching of oral English could be faced with in Nigerian secondary schools.

\section{Methodology}

The research was carried out using questionnaires to seek teachers' and students' opinions concerning the issue under investigation. The research participants 
consisted of teachers of English language and students, particularly; senior secondary schools students (SSSI-SSS III) within the four selected schools in Minna municipal namely Government day Secondary School, Minna; Government day Secondary School, Maitumbi; Ahmadu Bahago Secondary School, Minna and Government Secondary School, Minna.

In this investigation, 200 questionnaires were distributed to English Language teachers and students in the selected schools. However, only 182 were completed and returned, of which 101 were from students and 81 were from English Language teachers. Therefore, these 182 completed questionnaires are the ones from which the percentages were computed.

Table 1 shows the selected schools used and the number of questionnaires distributed to each of the schools. The number of questionnaires distributed to the schools varied according to the population capacity of both students and the subject teachers in each school.

Table 1

Distribution of questionnaires to teachers and students in four schools

\begin{tabular}{lcc}
\hline Name of School & $\begin{array}{c}\text { No. of } \\
\text { questionnaires } \\
\text { distributed to } \\
\text { teachers }\end{array}$ & $\begin{array}{c}\text { No. of } \\
\text { Qquestionnaires } \\
\text { distributed to } \\
\text { students }\end{array}$ \\
\hline $\begin{array}{l}\text { Government Day Secondary School, } \\
\text { Minna }\end{array}$ & 30 & 30 \\
$\begin{array}{l}\text { Ahmadu Bahago Secondary School, } \\
\text { Minna }\end{array}$ & 20 & 30 \\
$\begin{array}{l}\text { Government Secondary School, } \\
\text { Minna }\end{array}$ & 30 & 15 \\
Zarumai Model School, Minna & 20 & 25 \\
\hline Total: & 100 & 100 \\
\hline
\end{tabular}

\section{Results and Discussion}

Table 2 shows the enumerated factors and the number of responses against each factor by respondents as well as their percentages. However, it should be noted that the factors enumerated are directly or indirectly reflected in the questionnaires distributed. The degree to which each of the factors affects the teaching of Oral English is shown in numbers and percentages. 
Table 2

Summary of enumerated factors affecting teaching of Oral English

\begin{tabular}{|c|c|c|c|c|c|c|c|c|}
\hline \multirow[t]{3}{*}{ Factors } & \multicolumn{4}{|c|}{$\begin{array}{l}\text { Teachers } \\
(n=81)\end{array}$} & \multicolumn{4}{|c|}{$\begin{array}{l}\text { Students } \\
(n=101)\end{array}$} \\
\hline & \multicolumn{2}{|c|}{$\begin{array}{c}\text { No. of } \\
\text { Responses }\end{array}$} & \multicolumn{2}{|c|}{ Percentage } & \multicolumn{2}{|c|}{$\begin{array}{c}\text { No. of } \\
\text { Responses }\end{array}$} & \multicolumn{2}{|c|}{ Percentage } \\
\hline & Yes & No & Yes & No & Yes & No & Yes & No \\
\hline $\begin{array}{l}\text { 1. Interference } \\
\text { of mother } \\
\text { tongue }\end{array}$ & 66 & 15 & $81 \%$ & $19 \%$ & 90 & 11 & $89 \%$ & $11 \%$ \\
\hline $\begin{array}{l}\text { 2. Ineffective } \\
\text { teaching } \\
\text { methodology }\end{array}$ & 55 & 26 & $68 \%$ & $32 \%$ & 63 & 38 & $62 \%$ & $38 \%$ \\
\hline $\begin{array}{l}\text { 3. Shortage of } \\
\text { relevant } \\
\text { textbooks }\end{array}$ & 70 & 11 & $86 \%$ & $14 \%$ & 73 & 28 & $72 \%$ & $28 \%$ \\
\hline $\begin{array}{l}\text { 4. Lack of } \\
\text { orientation }\end{array}$ & 68 & 13 & $84 \%$ & $16 \%$ & 64 & 37 & $63 \%$ & $37 \%$ \\
\hline $\begin{array}{l}\text { 5. Lack of } \\
\text { constant } \\
\text { practice. }\end{array}$ & 71 & 10 & $88 \%$ & $12 \%$ & 82 & 19 & $81 \%$ & $19 \%$ \\
\hline $\begin{array}{l}\text { 6. Lack of } \\
\text { language } \\
\text { laboratories. }\end{array}$ & 44 & 37 & $54 \%$ & $46 \%$ & 55 & 46 & $54 \%$ & $46 \%$ \\
\hline $\begin{array}{l}\text { 7. Dearth of } \\
\text { necessary } \\
\text { facilities }\end{array}$ & 62 & 19 & $77 \%$ & $23 \%$ & 88 & 13 & $87 \%$ & $13 \%$ \\
\hline
\end{tabular}

On the interference of mother tongue on the teaching of Oral English in our secondary schools, the results confirm the hypothesis. The percentages of teachers and students with the opinion that mother tongue strongly affects the teaching of Oral English are $81 \%$ and $89 \%$ respectively.

The assumption that ineffective teaching method affects the teaching of Oral English was tested and the percentage of responses indicates that it also affects the teaching of Oral English. In the data collected, $68 \%$ of the teachers and $62 \%$ of the students think that effective teaching methods affects the teaching of Oral English.

The results show that shortage of textbooks also constitutes a problem to the teaching of Oral English in Nigerian secondary schools. Table 2 reveals that $86 \%$ of the teachers and $72 \%$ of the students felt that shortage of relevant textbooks affects the teaching of Oral English.

The lack of orientation on the significance of Oral English in ensuring competence in language use also affects the teaching of the course, as shown by $84 \%$ of teachers and $63 \%$ of students who reported that they were unaware of the significance of Oral English teaching in the acquisition of Oracy skills. This shows that 
there is the need for orientation for students and teachers on the significance of Oral English.

Practice is a physical activity. It also requires a confirmation on its relevance to effective teaching of this component of English Language. The responses received from the respondents show that lack of constant practice is seen as a problem hampering the effective teaching and learning of Oral English by $88 \%$ of teachers and $81 \%$ of students.

The essence of language laboratory in language teaching is to assist the learning (students) and to facilitate their understanding of the phonetics of a language. This problem states that lack of language laboratories affects the teaching of Oral English. However, in the data analysis, only $54 \%$ of teachers and $54 \%$ of students reported that lack of language laboratories also affects the teaching of Oral English. Language laboratories aid comprehension in Oral English teaching but it is not as important as other factors.

This problem affirms that the teaching of Oral English requires the use of other necessary relevant facilities, that is, teaching aids such as radio, tape recorder, television set, flash cards and resource persons that could also facilitate easier teaching, learning and understanding of the component. The results shows that $77 \%$ of teachers and $87 \%$ of students identify the dearth of necessary faciltiies as strongly affecting the teaching of Oral English.

From the analysis, the data collected through the responses from the questionnaires confirm that all the factors identified and enumerated as major challenges affecting the teaching of Oral English are valid. However, there are other challenges that are also affecting the teaching of this course, such as the misconception of the course by teachers, learners and users, the attitude of teachers to English Language teaching, lack of interest by many teachers and students; lack of emphasis from the onset, the existence of English varieties, lack of workshops or seminars for English Language teachers, lack of interest by many teachers and students, and lack of emphasis from the onset. On the other hand, students identified the existence of varieties of English, lack of workshops or seminars for English Language teachers and probably truancy on the part of the students.

The implications of the findings can thus be summarised in the following ways: Semantically, there is a shift from Standard English and this constitutes a departure from the target norms. It (may) constitute errors. It (may) bring about substandard forms which are neither acceptable nor intelligible to both native speakers as well as educated Nigerian users of Standard English.

\section{Summary of Findings}

The findings of the study as reflected in the questionnaires can be summarised as follows:

i. Interference of mother tongue - Nigeria is a multi-lingual nation and English language is mostly the second language of virtually every learner of English. 
Therefore, the phonetic sound system of the mother tongue affects the mastery of the target language. This leads to non- standard English.

ii. Ineffective teaching methodology - Statistics has shown that most of the teachers teaching in Nigerian secondary schools do not pass through teachers colleges. Therefore, they lack the professional skills needed to carry out their teaching assignments. This affects the teachers' ability to impact knowledge effectively.

iii. Shortage of relevant textbooks - Textbooks are very necessary in the teaching and learning process. They enhance the learners' understanding of what has been taught. The libraries in most public schools are not fully equipped to meet the needs of the learners. This also affects their proficiency especially in spoken English.

iv. Lack of orientation - Students need to be made aware on the need to be good in spoken English as this will enhance international intelligibility.

v. Lack of constant practice - Oral English is an aspect of language that is concerned with our ability to speak good English. Regular usage of standard pronunciation can lead to perfection. This is not the case with many students as they revert to the mother tongue immediately after the normal lesson or class hours.

vi. Lack of language laboratories - Language laboratories are very useful in carrying out practical phonology in our post primary schools. They allow the learner to carry out individualised instruction. These facilities are very scarce which affects the teaching of oral English.

vii. Lack of necessary facilities - This is not far from the ones mentioned above, but they are not the only facilities required for the teaching of oral English such as radio, television and improvised materials are not available for use. This affects the learners' competence in oral English.

\section{Conclusion}

In conclusion, it should be noted that our major concern in this research is the challenges facing the teaching of Oral English. The study shows that the major challenges facing the teaching of Oral English in our secondary schools are interference of mother tongue, effective teaching methodology, shortage of relevant textbooks, lack of orientation, lack of constant practice, and lack of necessary facilities but lack of language laboratories is not as crucial as the other six factors. It is pertinent to reiterate that oral proficiency in language use is invaluable and, as a matter of fact, a necessity to all learners of English as a second language. It manifests one's competence in language acquisition and use. Therefore, this study 
has focused on the teaching and learning situation of the course, particularly the challenges that are connected to its effective teaching in our secondary schools.

The study also attempts to offer possible solution (suggestions) that could improve the status of the course. The following are some recommendations based on this study:

- All learners of English Language should identify their problems in practical speech. Such identification will help to improve one's proficiency in oracy. It will also help the individual to avert the problem. The mother tongue or first language interferes a great deal with the second language to be learnt. Different Nigerian Languages have their own different ways of interfering with practical English.

- It is said that "practice leads to perfection." Learners of English as a second language should endeavour to learn, understand and practice the correct pronunciation of English phonemes or words in order to attain oral proficiency. The use of an English Dictionary could also be of great assistance.

- Effort should be made by individuals (students/teachers) in various schools to avoid the constant use of Pidgin English or vernacular languages as excessive use of these varieties could affects one's oral proficiency.

- There is the need to give orientation to teachers and students on the significance of the course. Teachers should be encouraged to attend workshops, seminars, refresher courses and the like in order to update their knowledge and improve on their teaching methodology.

- The government, private organisation or individuals should assist in providing necessary facilities as teaching aids such as television sets, radios, tape recorder, flash cards and other related facilities that will help in facilitating easier understanding of the course.

- The provision and availability of language laboratories in various schools will also encourage teachers and students to appreciate and put more effort in embracing the component.

- Teachers should provide a model in all aspects relating to English Language particularly Oral English. This can be on cassettes or discs.

- It is also advisable for learners of English as a second language to make time to listen to the British Broadcasting Corporation (BBC), Federal Radio Corporation of Nigeria (FRCN) and other Television networks. This will improve the learners listening and speaking skills.

- Emphasis on oracy skills should begin from the cradle (primary school) through all levels. This will make fluency in language use inherent among learners.

- Provision of relevant textbooks on the course should be made available to learners either by the government or through individuals' efforts.

- Application of penalty in terms of communication failure or laziness and how it should be done. Donough (1981) encouraged that in teaching second language in schools. This will also compel learners to adapt to learning conditions.

- Oral work should also take prominence in language teaching in the classroom. For instance, impromptu speech, news reading, news translation, speech acts, the use of dialogue, and conversations. 
- School management should ensure that only those who specialise in English Language should be allowed to teach the course or subject in both primary and post primary schools.

- Enough lesson periods should be allocated to the course in the lesson timetable in various schools. A minimum of three lessons for Oral English per week is hereby suggested.

- Curriculum planners should put into consideration the factors enumerated as affecting the teaching and learning of Oral English when planning the curriculum.

- It is recommended that this component of English Language is invaluable and indispensable in the teaching and learning process and language use in general. Consequently, much emphasis and concentration should be given to the course at all levels of learning. The quest for knowledge in Oral language is significant as English is considered as a global language.

- It is also recommended that similar research be carried out in other areas whether within or outside the state, so that the findings will also help to remedy the problems connected to the teaching of course in various secondary schools in Nigeria.

\section{References}

Anthony, E. C. (2001). Simplified approach to Oral English. Ibadan: Amora Publication.

Idris, U. (2001). Oral English. Lagos: Longman Nigeria.

Jones, D. (1917). English Pronouncing Dictionary. Hongkong: Wingkingtong Company Ltd.

Jowitt, D. (1991). Nigerian English usage. Lagos: Longman Nigeria.

Okoli, F.C. (2000). Communication in English. Onitsha: Thonik Prints Production Ltd.

Roach, P. (2000). Phonetics and phonology ( $3^{\text {rd }}$ ed.). United Kingdom; Cambridge University Press.

Unoh, S. O. (1986). Use of English in communication. Ibadan: Spectrum Books Limited.

Williams, D. (1990). English language teaching. Ibadan: Spectrum Books Limited. 